\title{
Construction of "Quaternity" Student Training Platform with Project as the Core
}

\author{
Mingchun Zhang \\ School of Information Science and Engineering \\ Beijing City University \\ Beijing, China
}

\begin{abstract}
In the context of the construction of new engineering disciplines, this study establishes a student growth training platform for the growth path of students. The platform guarantees student growth from four aspects: training plan, training form, training content, and platform management. Remarkable results have been achieved, and the construction benefits of the tripartite benefit of students, teachers and schools have been achieved.
\end{abstract}

Keywords—student growth; training platform; effectiveness

\section{INTRODUCTION}

As the Ministry of Education actively promotes the construction of new engineering disciplines [1], it is clear that the student-centered approach will promote the transformation of undergraduate teaching from "teaching well" to "learning well".

Beijing City University has grasped the core point of comprehensively improving the talent cultivation ability. The Faculty of Informatics has long focused on the cultivation of students 'practical ability, focusing on the students' training objectives to solve complex engineering problems, which is achieved through the entire "cultivation system". And after it is resolved, it is implemented in all aspects of training. In order to meet the overall objectives of the training program, four platforms for "Innovation Workshop", "Innovation and Entrepreneurship Training Programs for College Students", "Discipline Competition" and "Maker Spaces" extracurricular student practice and innovation ability training have been established, diversifying the cultivation of students' practical ability, systematizing the training system, standardizing the management process, and projectizing the training content.

The construction of the four platforms is centered on students, insisting on the emphasis on output, the practice under the guidance of theory, the cultivation on different levels, and the improvement of feedback. It pays attention to professional interdisciplinary, grade through training, teaching benefits teachers as well as students and schoolenterprise collaboration to educate people, through the construction of project-based complex engineering problems to cultivate students' practical and innovative abilities [2].

\author{
Hui Wang \\ School of Information Science and Engineering \\ Beijing City University \\ Beijing, China
}

\section{FORM AND BASIC CONTENT OF PLATFORM CONSTRUCTION}

\section{A. Innovation Workshop}

The Innovation Workshop is a branded project for the student training of the Faculty of Informatics. The Faculty is equipped with professional instructors to provide personalized guidance and services. The Innovation Workshop is the core and link of the four practice platforms for students in the Faculty, and the birthplace of high-level student projects and competition results in the Faculty. There are currently 11 studios [3] in the Innovation Workshop of the Faculty of Informatics. The Innovation Workshop of the Faculty of Informatics adheres to the concept of "the roots of innovation are in practice, and the spirit of entrepreneurship is innovation." It continues to deepen the education mechanism of "guiding people through education, building up people through practice, cultivating people through culture, and inspiring people through mechanisms", provides "one-stop" services for students of the Faculty so as to stimulate their enthusiasm for innovation and entrepreneurship and cultivate the integration of university students' innovative ability and entrepreneurial ability.

\section{B. Innovation and Entrepreneurship Training Programs for College Students}

Through the project-based approach, students can obtain knowledge through practice. It encourages college students to solve problems in their majors, enhances students' innovative ability, and trains high-level innovative talents that meet the needs of building an innovative country.

\section{Discipline Competition}

The Discipline Competition is to further cultivate the teamwork spirit of college students on the basis of college students 'innovation and entrepreneurship training projects, to cultivate students' ability to solve practical and complex problems, and to promote the curriculum reform of corresponding disciplines. It further stimulates learning interest and potential of students, selects and cultivates outstanding students through participating in off-campus competitions, and cultivates students' team spirit and innovative spirit. 


\section{Maker Space}

On the basis of the three practical platforms of Innovation Workshop, Innovation and Entrepreneurship Training Programs for College Students and Discipline Competition, Maker Space has established a "Maker Space" project, which aims to train students who are willing to start a business in a targeted manner.

\section{QUATERNITY PLATFORM CONSTRUCTION IDEAS}

During the construction process, the four platforms focus on the overall layout of the quaternity, and realize systematization of the training plan, diversification of the training form, projectization of the training content, and standardization of the training management in the design of the program, training form, training carrier, and management. The training plan is standard, the training form is the condition, the training content is the core, and management is the guarantee.

\section{A. Systematizing the Training Plan}

It is student-centered and student-oriented to build a fouryear continuous line of ability training system for students to solve complex engineering problems. The system is designed and implemented in stages and levels. Starting from the main body of the training system, there is a set of training goals for each subject. Each subject restricts each other and cooperates with each other to ensure the effective operation of the system. The specific four platforms are implemented in three levels, as shown in "Fig. 1".

The first level relies on the professional tutor system of the Faculty of Informatics to target first-year students, which focuses on professional interest training and basic skills training. It carries out innovative workshops and other activities in the first-year to cultivate students' basic skills training and awareness of solving complex problems from the freshman year. The second level is aimed at sophomores, and combines theoretical education in innovation and entrepreneurship with practical combat to improve students' professional skills and theoretical education in solving complex problems. The third level is aimed at senior students, focusing on subject competitions and maker space, and carrying out high-level innovation and entrepreneurship practice activities, subject competitions and maker education to improve students' practical ability on professional and complex issues.

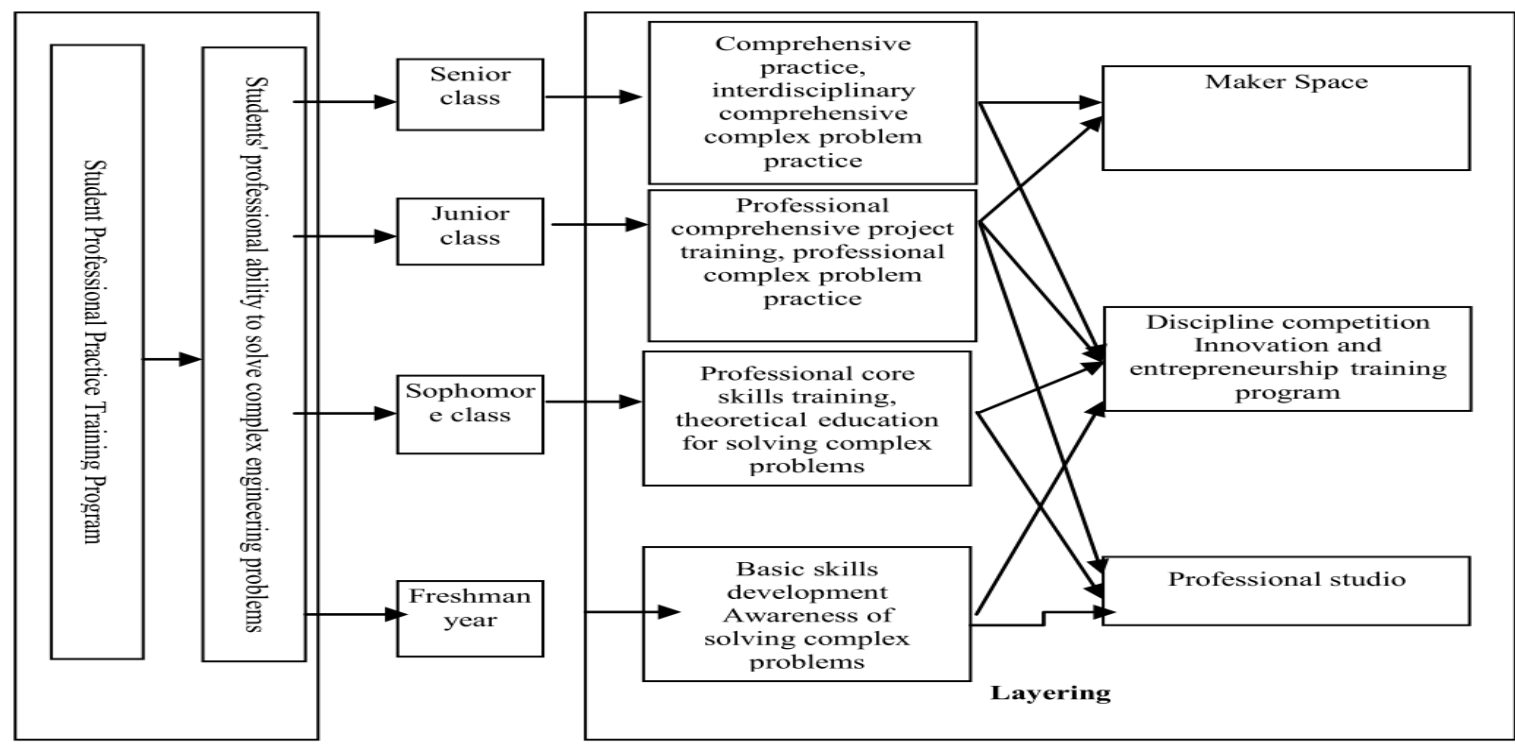

Fig. 1. Construction system of information major student training platform.

In addition, each platform also pays attention to its layering. For example, discipline competitions; the Faculty divides the competition into four levels: the first level is a platform competition that examines basic knowledge, the second level is a professional core competition that examines the core competence of students, and the third level is a professional comprehensive competition that examines the students' comprehensive quality and teamwork ability. The fourth level is to further excavate and improve the project based on the comprehensive competition to enable students to participate in high-level competitions outside the school.

For Innovation and Entrepreneurship Training Programs for College Students, its projects are divided into nationallevel and municipal-level projects. In addition, some less mature projects are mainly cultivated, and after one year of cultivation, they meet the standards of municipal-level or national-level projects.

For the studio setting, the studio is also constructed in accordance with the special ability studio and the comprehensive ability studio. In addition, in the process of team building, the studio pays attention to the layering of the students' grades and pays attention to the old to teach the new, basically realizing the composition of the students from the first year to the third year.

\section{B. Diversified Training Forms}

Cultivation forms include professional lectures, subject competitions, innovative training programs, student studios, 
entrepreneurial education in the annual financial budget, and has continuously increased investment. It actively encourages and supports teachers to participate in, and adopts a variety of incentive measures such as counting hours, subsidies, rewards, etc. to teachers guiding competitions, innovation and entrepreneurship project instructors, and innovation workshop instructors.

2) Plans and assessments for platform construction

The work of the four platforms is carried out with a work plan for the start of the school, a special discussion in the middle, and a summary assessment at the end of the semester.

\section{3) Feedback from students}

The Faculty attaches importance to timely feedback on the training results of the four platforms, and the feedback is divided into general feedback and special work feedback. The overall feedback is for the graduates, giving satisfaction to the four-year training of the four platforms of the university, and timely adjusting the training content of the platform according to the feedback results. The special work is to conduct student satisfaction surveys for each of the four platforms.

\section{PlATFORM CONSTRUCTION RESUlTS}

School of Information Science and Engineering has achieved remarkable results in the construction of the four platforms for many years, and has achieved the construction benefit of the three parties, including students, teachers and schools.

\section{A. Using Systematic Top-level Design to Promote Professional Construction}

The construction of the platform has a good feedback on the professional construction, which has established a benign student ability training cycle system.

The School has established a comprehensive student academic guidance team, which greatly improves the execution of student training. The Faculty has initially established four teams of instructors: a team of instructors for innovation and entrepreneurship training programs, an innovation workshop studio instructor team as well as a professional discipline competition leader team. After training, mentoring, and years of experience accumulation of the Faculty, the team has greatly improved the ability and level of team management. The Faculty has more than 60 teachers who undertake national and municipal innovation and entrepreneurship project mentors, and has hired more than 10 teachers as part-time entrepreneurial instructors. In recent years, the achievements of innovation and entrepreneurship have been promoted and implemented in the enterprise industry; they also have been recognized and praised by relevant departments, which has improved the school's popularity and reputation.

Innovative Workshop Studios, Innovation and Entrepreneurship Training Programs for College Students, Discipline Competition, Maker Space and teaching work promote each other, which promotes the projectization, production, and visualization of professional training student training programs for 6 consecutive years, has included the funds required for innovative and

\section{c) Guaranteed funding}

The Faculty of Informatics has implemented outstanding

and other forms; some are for all students, some are for key
training, and some are for students with special hobbies and department, coordinated by multiple departments and

b) Guaranteed regulations achieved outstand covation, and grants exemption from elective courses with the same credits, and replaces the provisions of graduation design (thesis) links. 
implementation of the project, students' practical and innovative abilities were greatly enhanced.

2) Increasing in the number and level of awards in highlevel, applied, and interdisciplinary competitions

In the past 3 years, the whole Faculty has carried out 120 innovation and entrepreneurship projects, including 16 crossgrade cross-projects (4 national-level) and 7 crossprofessional cross-involvement projects. In past three years, the students have won more than 20 national-level competitions, more than 160 provincial and ministerial competitions, and the number of competitions and the number of awards has increased year by year.

In 2017, Maker Space applied for a total of four "Internet $+"$ entrepreneurship projects, opening up 6 online courses and 3 offline trainings for students. The project has won multiple awards, including the China-US Maker Contest, the Internet + Maker Contest and so on.

\section{CONCLUSION}

The four-platform construction is a teaching concept and model that is produced to meet the needs of economic society and national development strategies. Based on the platform construction, the Faculty of Informatics provides students with a learning plan that is suitable for students based on their foundations, interests, and strengths, which is conducive to establishing personalized learning goals for students and giving students more autonomous learning spaces and platforms. It also combines individualized goals for success with the society's requirements for talents to achieve differentiated teaching services and educate people throughout the entire process, improving students' ability to practice and innovate, and thus improving their comprehensive ability and quality.

Of course, in the process of platform construction, there is also a lack of interdisciplinary research, and some platforms have weak links in project construction. The content of construction needs to be further improved. With the school's continuous investment in innovation and entrepreneurship education, the construction of the four platforms is bound to cultivate more high-quality innovative entrepreneurship talents for the construction of Beijing City University, and contribute more to the social development and regional economic construction of Beijing.

In the past three years, the platform has carried out nearly 120 innovation and entrepreneurship projects, more than 70 discipline competition projects and more than 40 innovation workshop projects.

\section{Using the Content-oriented Training Mode to Improve Students' Ability to Solve Complex Engineering Problems}

1) Students participate in practical projects and increase their ability to solve practical problems

In the past two years, the Faculty has undertaken more than 80 scientific research and social service projects. Relying on these scientific research and social service platforms and projects, the Faculty has adopted a series of measures to promote scientific research and social service projects to build training programs for students. During the

\section{REFERENCES}

[1] Wu Aihua, Hou Yongfeng, Yang Qiu, Bo Haojie. Accelerating the development and construction of new engineering disciplines, taking the initiative to adapt and lead the new economy [J]. Research in Higher Engineering Education, 2017.01, 1-9. (in Chinese)

[2] Zhang Yi. Constructing a system for cultivating students' scientific - Taking Harbin Institute of Technology as an example [J]. Modern Communication, 2019, (18), 163-164. (in Chinese)

[3] Pan Nana. Practical Research on the Cultivation of College Students' Innovative Practice Ability Against the Background of New Engineering Courses [J]. Contemporary Educational Practice and Teaching Research 2019, (17), 188-189. (in Chinese) and technological innovation ability based on the second classroom 